Saša Martinović, mag. paed.

Šahovski savez Zadarske županije

sasa.martinovic91@gmail.com

doc. dr. sc. Ivan Markić

Odsjek za pedagogiju, Filozofski fakultet u Zagrebu

imarkic@ffzg.hr

\title{
ŠAH KAO IZVANNASTAVNA AKTIVNOST
}

Sažetak: Izvannastavne aktivnosti kao različiti organizacijski oblici okupljanja učenika u slobodno izvannastavno vrijeme u školi imaju pretežito kulturnoumjetničko, športsko, tehničko, rekreacijsko ili znanstveno obilježje (Cindrić, 1992). Kroz njih učenici zadovoljavaju svoje potrebe i razvijaju kulturu korištenja slobodnog vremena. Zahvaljujući svom pedagoškom potencijalu, šah se sve više implementira u kurikulume škola i poučava na svim razinama obrazovanja. Ovaj trend počinje pratiti i Hrvatska, u kojoj se šah u mnogo škola provodi kao izvannastavna i/ili izvanškolska aktivnost.

U ovome radu prikazat će se $i$ analizirati prednosti koje bavljenje šahom ima za učenike osnovnih škola te će se empirijskim istraživanjam utvrditi pojavnost izvannastavne aktivnosti šaha u školama Grada Zagreba. Temeljem rezultata kvalitativnog istraživanja prikazat će se stavovi voditelja šaha kao izvannastavne aktivnosti o prednostima njegove implementacije, načinima utvrđivanja interesa te o načinima rada voditelja i polaznika/učenika.

Ključne riječi: nastavne metode, osnovna škola, učenik, usavršavanje učitelja

\section{UVODNA RAZMATRANJA}

Šah je igra za dva igrača koja se igra na šahovskoj ploči, odnosno šahovnici prema pravilima i zakonitostima koja su jedinstvena u cijelome svijetu, a propisala ih je Međunarodna šahovska federacija FIDE (franc. Fédération Internationale des Échecs).

Postoji više teorija o podrijetlu šaha. Glavni razlog tome je što su šahovnice pronađene čak u starim egipatskim i kineskim hramovima nastalima u svitanje civilizacije (Cvetnić, 2014). Ipak, postojanje šahovnice u to doba ne znači nužno i postojanje šaha kao igre pa je najraširenija, a i od FIDE (2009) priznata teorija, da je šah nastao u 6. st. u Indiji. Potekao je iz strateške igre koja se zvala čaturanga 
(vojska). Tu vojsku su predstavljale figure koje su činile pješaštvo, konjicu, slonove i bojna kola koja možemo usporediti s pješacima, skakačima, lovcima i topovima. Oko 600. godine, igranje šaha se širi u Perziju i to pod nazivom shatranj. Arapskim osvajanjem Perzije, šah postaje predmet i njihova interesa, počinje se proučavati iz matematičke i geometrijske perspektive te se počinju javljati prvi teoretičari ove igre. Preko Bizanta i Mediterana, šah je u 9. st. stigao i u zapadnu Europu i u Rusiju a do 1000. godine šah se proširio po cijeloj Europi (Golombek, 1980). Pravila su se s vremenom mijenjala, a današnja pravila svoju formu dobivaju krajem 15. stoljeća. Iako je najprije bio igra koja se igrala na dvorovima i među plemićima, u 18. stoljeću počinje biti dostupan široj populaciji. Prvi spomen šaha u Hrvatskoj nalazimo u inventaru jednog zadarskog trgovca iz 1385. godine. Osim toga, postoji i zapis iz Dubrovnika iz 1422. godine, a nešto kasnije i zapisi iz Splita i Rijeke (Sušić, 2006).

Danas je šah priznat kao mentalni sport od strane Međunarodnog olimpijskog odbora te većine zemalja EU-a. Razloge zašto je danas šah priznat kao sport Foley (2015) navodi: kompetitivnost, organizaciju, važnost fizičke pripreme, kodeks ponašanja, globalnost igre, mentalna komponenta, sistem rejtingiranja igrača itd. Prema podacima FIDE, najpopularniju igru na ploči igra oko 605 milijuna ljudi diljem svijeta (FIDE, 2012), a taj broj svakim danom raste sve više.

Šah je u svojoj biti strateška igra. Kako bi se došlo do pobjede, nužno je promišljanje svojih i predviđanje suparničkih poteza. Analizirajući faktore i prepreke na koje može naići u datoj poziciji, igrač donosi odluke. Donese li igrač ispravne odluke, bit će nagrađen pobjedom. Međutim, ako u partiji učini previše pogrešaka, vrlo je vjerojatno da će njegov protivnik iskoristiti pogreške i dovesti ga do poraza. Ipak, šah je toliko kompleksan i bogat mogućnostima ${ }^{5}$ da igraču otvara brojne druge mogućnosti kojima može popraviti svoju pogrešku i ostvariti prvotni cilj. Uvođenjem šahovskog sata kao dijela igre, igrače se obvezuje da te odluke donesu u zadanom vremenu, a navedeno implicira i odgovornost za utrošeno vrijeme te brzu procjenu trenutnog stanja i mogućnosti koje ima. Mogućnost popravka svojih pogrešaka iznimno je bitna odgojna poruka šaha koja igrača uči, ne samo koncentraciji i uzimanju u obzir različitih situacijski uvjetovanih čimbenika, već i tome kako svatko od nas može donijeti i krive odluke, napraviti pogreške, ali život kao i šah gotovo uvijek nudi druge mogućnosti za pozitivan ishod.

Čovjek igrajući šah igra igru koja imitira njegov život (Kasparov, 2009). Igrajući šah, kao i u životu, donosimo odluke uzimajući u obzir što više detalja, ali i moguće posljedice koje naše odluke mogu prouzročiti. No šah je i više od igre. To je intelektualna razonoda koja posjeduje umjetničke kvalitete i znanstvene elemente, igra i sport koja svoju primjenu nalazi u brojnim područjima života čovjeka. Jednu od svojih primjena šah kao igra i sport je pronašao u odgojno-obrazovnom

5 Već nakon drugog poteza crnoga moguće je čak 71852 različitih pozicija. Nakon četvrtog poteza taj broj raste na oko 315 milijardi mogućnosti! (Shenk, 2007) 
svijetu gdje se sve više i češće koristi i implementira te nudi kao izvannastavna ili izvanškolska aktivnost, a ponegdje i kao nastavni predmet. Glavni razlog tome su mnogobrojne prednosti koje bavljenje šahom pruža učenicima u različitim područjima osobnog razvoja. Od zemlje do zemlje se razlikuje način poučavanja u odgojno-obrazovnim institucijama. Tako u Hrvatskoj prevladava u obliku izvannastavne i izvanškolske aktivnosti, dok postoje zemlje u kojima je šah obvezan ili izborni predmet.

\section{ISTRAŽIVANJA O UČINCIMA I PREDNOSTIMA ŠAHA}

Jelovica (2012) ističe i tri razloga zbog kojih je šah idealan za provođenje istraživanja. To su: velik broj šahovske populacije, dovoljno jednostavna pravila da ga u kratkom periodu može naučiti svatko, a opet je toliko složen da ga nitko nikada neće savršeno svladati što omogućuje istraživačima brojnu populaciju za provedbu istraživanja, komparaciju rezultata kroz dugi period stjecanja šahovskih vještina, postojanje rejting sustava koji pokazuje razinu stručnosti šahista te postojanje velike arhivske baze podataka svih partija i rezultata šahovskih igrača. Šah je, prvenstveno zbog kognitivnih procesa koje uključuje, zanimljiv znanstvenim istraživačima, ali i praktičarima već preko 100 godina. Dizdar (2014) je sabrao iskustva i mišljenja iz šahovske prakse te izveo zaključke da šah: uči osobu vještini rješavanja problema, nagrađuje ustrajnost i strpljivost u rješavanju zadataka, potiče originalnost, inventivnost $i$ imaginaciju, razvija samopouzdanje, realnu procjenu vlastitih sposobnosti i poštovanje prema protivniku, uči odgovornosti, model je svijeta u stalnim promjenama na koje se pojedinac treba prilagoditi, zahtijeva sposobnost kvalitetne obrade informacija i brzog donošenja odluka, brzo razotkriva površnost i brzopletost, povezuje ljude neovisno o socijalnom i ekonomskom statusu, pomaže u socijalizaciji i sprječavanju štetnih navika...

Uz radove praktičara, osobni afinitet prema šahu iskazali su i mnogi znanstvenici. Prvo zabilježeno znanstveno istraživanje vezano za šah napravio je Alfred Binet (1894). Ovog psihologa, najpoznatijeg po prvim testiranjima inteligencije, za istraživanje je inspirirao šah na slijepo ${ }^{6}$ te je želio utvrditi postoji li povezanost između igranja šaha na slijepo i ljudskog pamćenja. Slična istraživanja proveli su Chase i Simon (1973) i de Groot (1978). Navedena istraživanja pokazala su da bolji šahisti imaju bolje razvijeniju memoriju što se tiče šahovskih pozicija, gdje šahisti bolje pamte šahovske pozicije po principu logičke smislenosti (Binet, 1894), te postojanje razlike u pamćenju pozicija iz šahovske prakse između različith kategorija sudionika istraživanja (izvankategornici i velemajstori). Chase i Simon (1973) su svojim istraživanjem potvrdili kako se izvanredna sposobnost pamćenja koja se može uočiti kod dobrih šahista ne preslikava na druge sfere djelovanja pa čak ni na šahovske pozicije koje nemaju logični šahovski smisao, dok

6 Šah na slijepo varijanta je šaha u kojoj igrači nemaju pravo gledati u šahovsku ploču i figure, već slike pozicija moraju memorirati, a poteze vući tako što ih verbalno najavljuju. 
je istraživanje de Groota (1978) utvrdilo kako razlike ne bi bile značajne u memoriranju kada bi figure bile razmještene bez nekog logičkog slijeda. Iz navedenih se istraživanja moglo zaključiti da šah ne poboljšava nužno vještine memoriranja kod ljudi, unatoč tome što navedeno možemo često čuti kao jednu od prednosti bavljenja šahom. No neka istraživanja utvrdila su određene razine povezanosti između bavljenja šahom i razvoja kognitivnih područja pojedinaca i grupa. Tako je Christiaenovo istraživanje (1976) pokazalo kako je skupina učenika petog razreda koja je jedan sat tjedno poučavana šahu (ukupno 42 sata), na kraju šestog razreda postigla značajno bolje rezultate na testiranjima od skupine koja se nije bavila šahom. Nadalje, Frank (1978) je proveo istraživanje na uzorku adolescenata u dobi od 16 i 18 godina. Oni učenici koji su se uz nastavu bavili i šahom (jedan sat tjedno), na kraju istraživanja pokazali su značajni napredak u prostornim, numeričkim i verbalnim sposobnostima u odnosu na skupinu koja nije imala šahovsku poduku. Ferguson (1986, prema Ferguson 1995) je dokazao da daroviti učenici uključeni $u$ šahovske skupine postižu bolje rezultate $u$ kreativnosti od darovitih učenika uključenih u drugačije aktivnosti. Gaudreau (1992, prema Ferguson 1995) je istraživao povezanost uključenosti šaha u nastavni program matematike (tri razine - program ne uključuje poduku šaha, poduka šaha i intenzivna poduka šaha) i uspjeha učenika. Dokazao je kako u zadacima koji su uključivali jednostavne računske radnje nije bilo statistički značajnih razlika u rezultatima svih grupa, no na zahtjevnijim zadacima posljednje dvije grupe postigle su značajno bolje rezultate. Ferguson (1995) je također utvrdio kako su nakon šahovske poduke učenici postigli malen napredak u rasuđivanju u odnosu na nacionalnu normu, ali osjetno veći napredak u pamćenju. Margulies (1996) je istraživao povezanost šaha i čitalačkih vještina učenika gdje su rezultati pokazali kako je grupa učenika koji su dvije godine vježbali šah pokazala značajno veći napredak u čitalačkim sposobnostima. Liptrap (1998) je proveo slično istraživanje čiji rezultati navode kako u trećem razredu nije postojala statistički značajna razlika između kontrolne i eksperimentalne skupine, no u petom razredu učenici eksperimentalne skupine (šahisti) postigli su značajno bolje rezultate u čitanju i matematici. Trinchero (2013) je proveo istraživanje u kojem je utvrdio kako su članovi skupine koja je cijelu školsku godinu podučavana šahu uz pomoć šahovskog trenera i računalnih programa, postigli značajno bolje rezultate na PISA testu iz matematike. Iako prikazana istraživanja pokazuju prednosti koje igranje šaha pruža i u drugim sferama života, postoje i oni koji su skeptični prema kvaliteti tih istraživanja. Najpoznatiji rad na tu temu napisali su Gobet i Campitelli (2006). Oni navode i ističu potrebu opreznosti pri isticanju tvrdnji da bavljenje jednom aktivnosti pridonosi kognitivnom razvoju u drugim sferama.

Osim navedenih prednosti bavljenja šahom, Pavičić Vukičević (2013) uočava i onu da je šah u svojoj biti igra te povezuje šah s pozitivnim aspektima igre općenito. U svojoj knjizi Homo Ludens, Huizinga (1992, prema Pavičić Vukičević 2013) 
govori o povijesnoj važnosti igre za čovjeka i zaključuje da igra zapravo prethodi razvoju kulture. Pritom ističe tri bitne dimenzije igre: biologijsku, psihologijsku i ludičku (kulturnu). Biologijska dimenzija podrazumijeva fiziologijski uvjetovane psihičke reakcije kao što su: opuštanje od viška životne snage, nagon za oponašanje, priprema za ozbiljnije aktivnosti, strast za vladanjem, želju za nadmetanje s drugima, vježbe za samosvladavanje, nadoknađivanje za nešto neostvarivo i dr., psihologijska dimenzija igre odnosi se na spoznaju čovjekova duha, zahvaljujući kojemu igra postaje moguća. Kroz igru čovjek nadilazi područje fizičkog, što se vidi kroz različiti intenzitet napetosti, radosti i razonode igrača. Kulturna dimenzija igre je sveprisutna. Prema ovom aspektu, igra je sastavni dio kulturnog života te je društveno konstruirana smislena aktivnost (Huizinga 1992, prema Pavičić Vukičević 2013). Stoga možemo zaključiti kako šah kao igra zadovoljava i imanentnu ljudsku potrebu koja održava psihičku ravnotežu budući da je ona ugodna i opuštajuća aktivnost kojoj se čovjek predaje kako bi se udaljio od svakodnevne rutine (Piaget, 1981).

\section{METODE POUČAVANJA ŠAHA}

Nakon snažne kritike tradicionalnom pristupu nastavi, početkom 20. st. javljaju se mnogi alternativni pedagoški pravci poput Montessori sustava, Freinetove škole, Dalton-plana, Winnetka plana, Jena-plana, Waldorfske škole i dr. (Matijević, 2001). Ideja koja je zajednička svim navedenim alternativnim pravcima je promjena modela ,stare škole”. Takvu školu karakterizira frontalni rad učitelja, memoriranje informacija i njihova kasnija reprodukcija u svrhu dobivanja što bolje ocjene. Iako je ovaj opis nažalost često prisutan i u današnjim školama, alternativni pedagoški pokreti ipak su pokrenuli novi val pedagoških razmišljanja. Tako niz autora (Armstrong, 2008; Glasser, 2005; Matijević i Radovanović, 2011; Meyer, 2005; Sahlberg, 2011; Terhart, 2011; Vrcelj, 2000) piše o nedostacima ovakve prakse i promiču jednu novu pedagogiju, usmjerenu na učenika. Prema njihovim razmišljanjima u nastavi se trebaju kombinirati različite metode učenja i poučavanja, učenik postaje aktivan subjekt odgojno-obrazovnog procesa, dok svrha cijelog procesa nije samo pamćenje činjenica, već razvoj čovjeka koji zna samostalno kritički razmišljati, rješavati probleme i primjenjivati naučeno. O važnosti raznolikosti metoda poučavanja u nastavi pisali su mnogi autori (Bognar i Matijević, 1993; Meyer, 2005; Poljak, 1980; Terhart, 2001) koji su jednoglasni u tome da ne postoji savršena metoda poučavanja, već ona treba ovisiti o raznim čimbenicima poput posebnosti učenika, sadržaja, mogućnosti ostvarenja željenih ishoda, potentnosti metode za ostvarenje više nastavnih ciljeva, opremljenosti učionice, znanja učitelja i sl. Većina tradicionalnih didaktičkih metoda primjenjiva je i u poučavanju šaha. Tako je metoda usmenog izlaganja s potom i demonstracije prvi korak kojim se učitelj služi u poučavanju učenika pravilima i općim principima šaha. Metoda razgovora je konstantno prisutna u poučavanju šaha putem diskusije koju 
Poljak (1980) navodi kao najviši oblik razgovora. Upravo je metoda razgovora najprisutnija u praksi jer je šah i filozofska igra u kojoj često nema jedinstvenog rješenja, već nerijetko na temelju boljih argumenata ocjenjujemo snagu nekog poteza. Uz poštivanje tradicionalnih metoda poučavanja učenik uči i na druge načine, uvidom, analizom, promatranjem, promišljanjem, aktivnošću te kreiranjem vlastitog modusa učenja gdje povratne informacije mogu biti trenutačne ali i dobivene analizom vlastitih postupaka. U tom procesu uloga učitelja transformira se u onu pomagača, kritičkog prijatelja, savjetnika, usmjeravatelja i onoga koji ostaje uzor i stručnjak koji je dostupan i spreman pomoći. Sa svime navedenim možemo povezati i razmišljanja Meyera (2005) koji raznolikost nastavnih metoda navodi kao jedno od obilježja dobre nastave.

\section{ŠAH KAO IZVANNASTAVNA AKTIVNOST}

Prema 2. članku Državnog pedagoškog standarda "izvannastavna aktivnost je oblik aktivnosti koji škola planira, programira, organizira i realizira, a u koju se učenik samostalno, neobvezno i dobrovoljno uključuje" (NN, 2008a). Cindrić (1992) definira izvannastavne aktivnosti kao različite organizacijske oblike okupljanja učenika u slobodno izvannastavno vrijeme u školi, koji imaju pretežito kulturno-umjetničko, športsko, tehničko, rekreacijsko i znanstveno (obrazovno) obilježje. Kroz njih učenici zadovoljavaju svoje stvaralačke i rekreativne potrebe, a posebice stječu kulturu korištenja slobodnog vremena. Uključivanjem učenika u takve aktivnosti zadovoljavaju se njihove obrazovne, ali i odgojne potrebe, želje, interesi i traženja. One se učeniku nude kao način ispunjavanja slobodnog vremena koje je jedan od pedagoški potentnijih, ali često zanemarivanih područja života mladih u kojemu postoji prostor i mogućnost interakcije u procesima individualizacije, socijalizacije i inkulturacije koje služi za razvoj samoaktualizacije i ostvarenja osobnosti (Previšić, 2000). Izvannastavne aktivnosti je zakonom obvezno provoditi u školama i to od 1953. godine kada su pod nazivom "slobodne aktivnosti" uvedene u naše škole (Previšić, 1985). Mlinarević i Brust (2009) kao preduvjete za kvalitetno pedagoški osmišljene izvannastavne aktivnosti navode potporu voditelju izvannastavne aktivnosti, samostalnost voditelja u izboru programa, uključenost učenika u aktivnosti te konstantno stručno usavršavanje voditelja za aktivnost koju organizira. Sadržaj i aktivnost šaha pripada športsko-zdravstvenom području i dio je Nastavnog plana i programa (2006). Procedura za organiziranje šaha kao izvannastavne aktivnosti ista je kao i za sve ostale izvannastavne aktivnosti. Uoči li se među učenicima interes za šah ili netko od sudionika odgojno-obrazovne ustanove (npr. učitelj, stručni suradnik, roditelj itd.) predloži ili preporuči uvođenje šaha u školu, tada o tome odlučuje školski odbor prema Zakonu o odgoju i obrazovanju u osnovnoj i srednjoj školi (Narodne novine, 2008b).

Poticanje uvođenja šaha, ali i drugih izvannastavnih aktivnosti u kurikulume škola nije zadaća samo pojedinaca i entuzijasta koji će osluškivati „bilo” učenika. 
Prvi značajni korak provođenja ideje implementacije šaha u kurikulume škola u praksi učinjen je 1984. kada FIDE osniva posebnu komisiju za uvođenje i implementaciju šaha u škole. Najveći doprinos projektu šaha u školama na europskom tlu svakako je Deklaracija o uvođenju programa „Šah u škole" u obrazovni sustav Europske unije, koju je 15. ožujka 2012. izglasao Europski parlament koji navodi dobrobiti šaha u razvoju dječje koncentracije, strpljenja, upornosti, kreativnosti, intuicije, pamćenja, analitičkih vještina, odlučnosti, motivacije i sportskog ponašanja (EU, 2012). Također moramo istaknuti i posebnosti određenih zemalja poput Turske, Armenije i Rusije koje šahu pridavaju sve veći značaj i mjesto unutar odgojno-obrazovnog sustava i koje su u svoje obrazovne kurikulume uvele šah u različitim oblicima poučavanja.

U Hrvatskoj se izvannastavni rad s učenicima kroz šahovske sekcije/grupe počeo odvijati još 1977. godine u Zagrebu. Organizator su bile šahovske škole, a one često i danas, pod nadležnošću matičnog sportskog saveza, sudjeluju u organiziranju izvannastavnih i izvanškolskih aktivnosti. U Hrvatskoj djeluje preko 40 šahovskih škola, koje u suradnji sa školama organiziraju rad s učenicima. Osim toga, Savez učeničkih sportskih klubova glavni je nositelj sportskih pa tako i šahovskih školskih natjecanja koje se odvijaju na svim razinama (školskim, gradskim, županijskim i državnim). Prema istraživanju iz 2012. godine izvannastavne šahovske aktivnosti održava gotovo 200 osnovnih škola. U njih je uključeno preko 4000 učenika i nešto manje od 150 voditelja. Voditelji su većinom djelatnici same škole, ali oko jedne trećine njih čine i vanjski suradnici-šahisti (Dizdar, 2014).

\section{OBRAZOVANJE ŠAHOVSKIH UČITELJA ${ }^{7}$}

Implementacija šaha i njegovo poučavanje u osnovnim školama povlači sa sobom bitno pitanje, a to je: “Tko bi ga trebao poučavati?". Problem koji se veže s ovim pitanjem je zasigurno glavni razlog zašto mnoge škole nemaju organizirane šahovske aktivnosti. U praksi obično postoje dva rješenja. Jedno je da vanjski suradnici-šahisti dolaze u škole te drže šahovske sekcije, a drugo da to čine učitelji koji su već zaposleni u školi i poznaju barem osnove šahovske igre. No, dolazak šahovskih stručnjaka u škole ne znači da imaju i potrebne pedagoške kompetencije za rad u školi. S druge strane, prebacimo li ovaj zadatak isključivo na odgojno-obrazovne djelatnike, postoji opasnost da oni nisu dovoljno šahovski kompetentni, a moguće je da neke škole nemaju djelatnike koji dovoljno dobro poznaju šah. U nastavku ćemo predstaviti modele i analizirati neka moguća rješenja ovog problema.

Termin „šahovski učitelj“ u ovom radu predstavljat će osobu koja poučava šah u školi. Razlikuje se od termina ,„̌ahovski trener/ instruktor“ jer se potonji češće koriste u kontekstu šaha kao sporta te češće rade u šahovskim klubovima. 


\section{a) Model obrazovanja šahovskih učitelja svjetske šahovske federacije (FIDE)}

Svjetska šahovska federacija FIDE najraširenija je organizacija koja se bavi pitanjem šaha $u$ odgojno-obrazovnim sustavima. Ova organizacija rješenje nudi organiziranjem tečajeva te licenciranjem polaznika tih tečajeva. Uspješno položen tečaj i dobivena diploma trebali bi značiti da su polaznici stekli potrebne kompetencije za poučavanje šaha u školama. Ovakvi seminari održavaju se diljem svijeta, a izdvojili bismo dvije različite vrste, Seminari FIDE trenerske komisije ${ }^{8}$ i Seminari za titulu FIDE školskog instruktora. ${ }^{9}$

Seminari FIDE trenerske komisije. Trenerska komisija FIDE, osnovana je 1998. godine, s ciljem okupljanja najboljih svjetskih šahovskih trenera te prepoznavanjem, obrazovanjem i licenciranjem šahovskih trenera i instruktora diljem svijeta. Prema syllabusu Trenerske komisije posjedovanje prve dvije razine (razvojni instruktor i nacionalni instruktor) dovoljne su za poučavanje šaha u školi budući da obje imaju kategoriju školskog učitelja. Iz ovog syllabusa se da iščitati da je stjecanje čak i dviju najnižih titula dovoljno za stjecanje kompetencija šahovskog učitelja u školi i diplome koja jamči da je trener/instruktor sposoban obavljati taj posao nakon četverodnevnog seminara i odslušanih 15 sati predavanja. Iz pedagoške perspektive problem ovakvih seminara jest $u$ tome što ne razvijaju dovoljno pedagoško-didaktičko-metodičke kompetencije učitelja koje su potrebne za rad s djecom.

Seminari za titulu FIDE školskog instruktora. Ideja za pokretanje seminara za titulu FIDE školskog instruktora nastala je 2012. godine i predstavlja zaokret u odnosu na prvi model. Naime, dok su u prvom modelu polaznici šahisti, koji bivaju licencirani na temelju svojih šahovskih kompetencija, ovaj model namijenjen je prvenstveno učiteljima koji bi trebali poznavati samo osnove šahovske igre. Točnije, seminar mogu upisati svi koji: a) poučavaju ili će poučavati šah u školama, b) posjeduju znanje o psihologiji i pedagogiji i c) posjeduju dobro znanje o šahovskim osnovama. Seminari traju tri ili pet dana kroz koje polaznici odslušaju 15 sati predavanja (Uvod u šah, Šahovska kultura, Pedagogija i šah...) nakon čega polažu ispit. Samim time može se zaključiti da je ovaj model obrazovanja privlačniji od prethodnog ako govorimo o šahu u školama. Prednost modela je što polaznici dolaze iz neposredne odgojno-obrazovne prakse i usmjerenost na licenciranje budućih šahovskih učitelja u školama, dok je prethodni uključivao i obrazovanje za šahovske trenere, koji ne rade u školama, nego pomažu u razvoju profesionalnih šahista. Iako se može pretpostaviti da oni koje uspješno završe ovaj seminar te dobiju titulu FIDE školskog instruktora doista imaju potrebne pedagoško-psihološko-didaktičke-metodičke kompetencije, teško je zamisliti da je 15 sati dovoljno za stjecanje potrebnih šahovskih kompetencija. Unatoč tome što je

\footnotetext{
$8 \mathrm{http}: / /$ trainers.fide.com/

9 http://cis.fide.com/
} 
dovoljno steći samo osnove, šah je svejedno vrlo kompleksna igra pa je glavna zamjerka ovom modelu nedovoljna šahovska obuka. No, model poput ovakvoga ima potencijala te bi se problem mogao riješiti daljnjim stručnim usavršavanjem šahovskih učitelja. Kao potencijalno rješenje bi se moglo ponuditi intenzivnije uključivanje Hrvatskog šahovskog saveza u procese stručnog usavršavanja šahovskih učitelja u školama. Hrvatski šahovski savez bi u suradnji sa školama mogao organizirati seminare i radionice u kojima bi profesionalni šahisti dodatno poučili učitelje o šahu. Kroz ovakav bi se sustav u kratkom vremenu mnoštvo učitelja moglo obrazovati za kvalitetno poučavanje šaha u školama.

\section{b) Obrazovanje šahovskih učitelja na fakultetima u Hrvatskoj}

Proučavajući syllabuse hrvatskih sveučilišta, može se ustanoviti da samo Zagrebačko sveučilište ima mogućnost obrazovanja budućih učitelja za šah u školi. Riječ je o Učiteljskom fakultetu, odnosno o njegovim podružnicama u Čakovcu i Petrinji. Tamo se od 2008. provode izborni kolegiji Šah u osnovnoj školi 1 koji se bavi osnovama šaha i metodici poučavanja istih i Šah u osnovnoj školi 2 koji se bavi produblijivanjem teorijskog znanja o šahu, razlikama u percepcijama kretanja figura i prostora, poboljšanju pamćenja pomoću šaha, mogućnosti korištenja računalne tehnologije za šah itd. Osnivači su prof. dr. sc. Đuro Blažeka i prof. Siniša Režek.

Nakon pregleda različitih mogućnosti obrazovanja učitelja za poučavanje šaha u osnovnim školama može se izvesti nekoliko zaključaka. Kao prvo, glavna problematika vezana je za pitanje trebaju li se obrazovati šahisti kako bi postali kompetentni za rad u školi ili se učitelji trebaju obrazovati za bolje poznavanje šahovske igre. Šahisti praktičari ne moraju imati izvanredno šahovsko znanje, nego su važnije njihove pedagoško-psihološko-didaktičko-metodičke kompetencije kojima će kod djece potaknuti interes za ovu drevnu igru. Idealno bi bilo da je što više učitelja visoko kompetentnih u obje sfere, ali praksa pokazuje da je takvih vrlo malo. Druga bitna pretpostavka je kultura zemalja u kojima se provodi šah u školama. Preslikavanje modela razvijenijih zemalja u Republici Hrvatskoj, u kojoj šah još uvijek nije toliko popularan, nije moguće, stoga kao mogućnost razvoja trenutne situacije ističemo suradnju škola i Hrvatskog šahovskog saveza putem organiziranja različitih seminara usmjerenih prema potrebnim područjima razvoja učitelja, uključenost i suradnju stručnih suradnika pedagoga u organizaciju učenja šaha te zajedničku analizu rada voditelja/učitelja šaha.

\section{METODOLOGIJA EMPIRIJSKOG ISTRAŽIVANJA}

Cilj ovog istraživanja jest istražiti i utvrditi koliko osnovnih škola u Zagrebu provodi šah kao izvannastavnu aktivnost, tko je sve i na koje načine uključen u organizaciju i provedbu aktivnosti te ispitati i utvrditi stavove voditelja o različitim elementima provedbe šaha kao izvannastavne aktivnosti. 
Na temelju teorijskog dijela rada u kvalitativnom dijelu empirijskog istraživanja pokušalo se doći do odgovora na sljedeća istraživačka pitanja:

1. Koji su načini uočavanja interesa učenika za šah?

2. Koje metode koriste šahovski voditelji u šahovskoj nastavi?

3. Koje su aktivnosti u šahovskoj nastavi omiljene među učenicima?

4. Koje su mogućnosti poboljšanja kvalitete provedbe šaha kao izvannastavne aktivnosti?

5. Koje prednosti učeničkog bavljenja šahom ističu šahovski voditelji?

Kako bismo dobili jasniju sliku o trenutnom stanju provedbe šaha kao izvannastavne aktivnosti, analizirani su školski kurikulumi zagrebačkih osnovnih škola dostupni online te je uvrđeno kako od 108 osnovnih škola, šah kao izvannastavnu aktivnost nudi njih 32. Voditeljima aktivnosti šaha poslani su upitnici kojima se ispitivala struktura polaznika i voditelja izvannastavne aktivnosti. U prvom dijelu istraživanja pristalo je sudjelovati 25 voditelja od kojih je njih 7 kasnije sudjelovalo u kvalitativnom dijelu istraživanja provedenom putem polustrukturiranog intervjua.

Rezultati obrade ispunjenih upitnika pokazali su kako je struktura polaznika i voditelja šaha kao izvannastavne aktivnosti takva da je većinom biraju osobe muškog spola. Prema podatcima voditelja, dječaci upisani na šah čine $76 \%$ ukupne populacije polaznika, dok je kod $24 \%$ sudionika istraživanja odgovor bio da su grupe u školama spolno ujednačene. Rezultati pokazuju kako se na šah kao izvannastavnu aktivnost odlučuju većinom učenici razredne nastave (76\%), dok u $16 \%$ škola su to učenici predmetne nastave. Samo dvije škole (8\%) imaju jednak omjer polaznika. Što se tiče mogućnosti polaženja, rezultati su takvi da pokazuju kako u preko $90 \%$ osnovnih škola svi zainteresirani učenici budu i primljeni, a broj polaznika varira od 20 do 40 . Struktura voditelja šaha kao izvannastavne aktivnosti takva je da je $84 \%$ čine muškarci. Stalni zaposlenici škole čine $80 \%$ uzorka, dok njih 60\% nema nikakvu šahovsku titulu. Ostali sudionici istraživanja naveli su kako imaju titule različitih kategorija (od I kategorije do FIDE majstora). Neki oblik usavršavanja koristilo je 36\% voditelja, dok čak njih $88 \%$ ističe kako žele polaziti stručno usavršavanje.

\section{REZULTATI I INTERPRETACIJA}

\section{Načini uočavanja interesa za šah}

U teorijskom dijelu navedeno je kako je prije organiziranja bilo koje izvannastavne aktivnosti nužno prvo utvrditi postoji li interes učenika za nju. Odgovori na ovo pitanje ponudili su i dva posebno specifična i zanimljiva načina uočavanja interesa. To su odgovori sudionika 1 i 2 koji su rekli da su u školama prvotno organizirali šahovsko školsko prvenstvo. Budući da je sudjelovalo puno učenika, ustanovilo se postojanje interesa za šah te je organizirana izvannastavna aktivnost. 
Sudionici 3 i 4 su u školi dali oglas da se jave učenici zainteresirani za šah nakon čega se javio dovoljan broj zainteresiranih. Drugi načini bili su ispitivanjem mišljenja i interesa putem ankete (S5), želja voditelja (S6), dok je u jednom slučaju šah nastavila provoditi osoba (S7) koja nije imala saznanja kako je prvotno utvrđen interes polaznika. Dok su procjene školskih djelatnika, oglasi i ankete uobičajene metode ispitivanja interesa za osnivanje izvannastavne aktivnosti, organiziranje školskog natjecanja je metoda specifičnija i primjerenija za utvrđivanje interesa i popularizaciju šaha.

\section{Metode rada šahovskih voditelja}

Budući da je ovo pitanje otvorenog tipa, odgovori su se razlikovali. Zajedničko svim sudionicima istraživanja je da dopuštaju igranje slobodnih partija, ali i korištenje individualiziranog pristupa učenicima. Npr. Sudionik 1 navodi kako mlađi učenici najprije 10 do 15 minuta igraju partije, a onda slijedi nastava kroz zadatke, dok stariji prvo kreću s tematskim zadacima pa tek na kraju međusobno igraju. Kao razlog ističe da mlađi učenici posebno vole igru i natjecanje. Individualizacija je prisutna u šahovskim razinama. Tako se početnike uz frontalni način i individualno poučava bontonu i sportskom ponašanju, dok se s naprednijim učenicima prema potrebi uče konkretne šahovske operacije. Sudionik 2 svaki sat započinje provjerom domaćih zadataka koje redovito zadaje učenicima. Potom zajedno s učenicima radi na usvajanju sadržaja prateći šahovske udžbenike, a na kraju se igraju partije ili rješavaju problemski zadaci vezani za temu. Sudionik 3 ne radi na usvajanju novih sadržaja frontalnim radom i predavačkom metodom, već učenici rješavaju tematske zadatke primjerene njihovoj šahovskoj razini. Metodu predavanja iznimno koristi u slučaju kada učenici ne znaju osnovna pravila. U slučaju početničkih grupa odgovori svih sudionika istraživanja su istovjetni što je i opravdano s obzirom na ekonomičnost u mogućnosti poučavanja većeg broja djece. Nadalje, sudionici 3 i 7 često naglasak stavljaju na suradnički oblik rada učenika u kojem učenici koji više znaju poučavaju one koji znaju manje. Sudionici 4 i 6 naglašavaju da s početnicima treba prvo doći do razine da se može koristiti šahovske udžbenike, stoga njima prvo postavljaju lakše zadatke kako bi dobili osjećaj za kretanje figura po ploči. Sudionik 6 za tu svrhu ima i niz samostalno izrađenih nastavnih listića s primjerenim zadacima. Sudionik 7 napominje da su primjereni zadaci i slobodne partije najefikasnija metoda jer učenici aktivno uče, a njegova uloga je da konstantno hoda od stola do stola, savjetuje ili odgovara na postavljena pitanja. Ističe da vođenje šaha nije nimalo jednostavno te da neprestano ima interakciju s učenicima. Kao metodu voli koristiti i usmeno izlaganje učenika na način da rješenja zadataka učenici izlažu pred svojim kolegama. Sudionik 1 dodaje da za naprednije grupe organizira i dolaske iskusnijih šahista kako bi održali predavanja. Pri odgovoru sudionika istraživanja vidljivo je poštivanje didaktičkih načela u radu, posebice načela postupnosti gdje se voditelji oslanjaju na sukonstrukcijski 
proces u stjecanja znanja učenika, prilagođavajući metode i oblike rada stupnju upoznatosti sa sadržajem i slijede osnovna pravila postupnosti (od poznatog ka nepoznatom, od bližeg ka daljem, od jednostavnog ka složenom te od konkretnog ka apstraktnom). Također je prisutno i načelo individualizacije u kojemu svakom učeniku pristupaju individualno prateći njihove posebnosti, potrebe i želje u procesu napredovanja.

\section{Omiljene aktivnosti učenika u šahovskoj nastavi}

$\mathrm{Na}$ ovo pitanje nije bilo previše varijacija u odgovorima. Sudionici 3, 5 i 6 navode da učenici najviše vole igrati slobodne partije. Sudionici 1, 2 i 4 odgovor proširuju i kažu da je učenicima omiljena bilo koja metoda koja uključuje natjecanje. Odgovori sudionika istraživanja usmjeravaju nas prema rječima Huizinge (1992, 98): "U početku svakog natjecanja jest igra tj. sporazum, prema kojem se unutar nekih prostornih i vremenskih granica te po određenim pravilima i u određenom obliku ima izvršiti nešto što uzrokuje razrješenje napetosti, te je izvan uobičajenog životnog toka." To osim same igre, može podrazumijevati i natjecanje u rješavanju zadataka. Štoviše, Sudionik 1 navodi da korištenje razrađenog sustava bodovanja za bilo kakvu šahovsku aktivnost pa tako i rješavanje zadataka. Jedino Sudionik 7 kaže da njegovi učenici čak i više od igranja slobodnih partija, vole rješavati zadatke jer iz toga puno nauče, budući da se sve odvija u opuštenoj atmosferi. Sudionik 2 istaknuo je da je učenicima vrlo zanimljivo održavanje šahovskih simultanki. Natjecanje kao fenomen vrlo je blisko djeci i odvija se svakodnevno te im daje vrijeme i mjesto za potvrdu i iskušavanje svojih znanja i sposobnosti u odnosu na druge, daje priliku uvidjeti načine na koji drugi koriste svoja znanja, dobivaju povratne informacije vlastitom uspjehu ili neuspjehu, vježba koncentraciju, strpljenje i razvija osjećaje uvažavanja, kreativnst, sportskog ponašanje i sl. Natjecanje u kojemu pokazuju naučeno, ukoliko rezultira uspjehom, značajno utječe na razvoj samopouzdanja osobe, dok ih poraz uči prihvaćanju i kontroli negativnih emocija te usmjerava želji k daljnjem napredovanju.

Dakle, iz odgovora na drugo i treće istraživačko pitanje vidljivo je prilagođavanje individualnim razinama i potrebama učenika te korištenje raznih načina poučavanja i usavršavanja šaha, među kojima se ističu praktično odigravanje šahovskih partija i rješavanje postavljenih šahovskih zadataka/problema. Te aktivnosti su često popraćene dijalogom s voditeljem čije je svrha pomoći učenicima i razjasniti nejasnoće.

Mogućnosti poboljšanja kvalitete provedbe šaha kao izvannastavne aktivnosti

Sudionici 2, 3, 4 i 6 izdvajaju problem obrazovanja šahovskih učitelja i ističu nužnost dodatnog unaprjeđivanja programa šahovskog obrazovanja. Sudionik 6 poseban naglasak stavlja na pedagoško usavršavanje vanjskih suradnika šahovske profesije. Također ističu važnost suradnje škola s drugim institucijama. Tako 
Sudionik 2 kaže da škole moraju surađivati sa šahovskim klubovima i imati podršku lokalne zajednice, Sudionik 4 zagovara veće uključivanje i suradnju s nadležnim ministarstvom, a Sudionik 6 misli da Hrvatski šahovski savez treba poduzeti više za unaprjeđenje položaja šaha u školama. Tehnička opremljenost škola također je identificirana kao problematična (S3 i S5), kao i potreba jasnijeg određenja ishoda šahovske nastave (S1). Sudionik 7 ističe problem termina za šahovsku nastavu gdje je problem škola koje rade u više smjena te raspored igrača u dobne i jakosne skupine. Kao mogućnost poboljšanja provedbe šaha i podizanja kvalitete nastave sudionici istraživanja vide i stručna usavršavanja šahovskih voditelja. Sudionici 2, 3, 4 i 5 ne poznaju nikakav oblik stručnog usavršavanja po pitanju šaha u školama te smatraju da je to veliki problem. Sudionik 6 je kao oblik usavršavanja za studente koji planiraju biti učitelji izdvojio kolegije Šah u školi 1 i Šah u školi 2 koji se održavaju na zagrebačkom Učiteljskom fakultetu, dok Sudionik 7 zna za seminare FIDE, koje je i sam pohađao, ali o njima nema pozitivno mišljenje.

\section{Prednosti učeničkog bavljenja šahom prema šahovskim voditeljima}

Na navedeno pitanje sudionici istraživanja dali su pregršt odgovora koje je teško generalizirati pa će biti redom navedeni. Sudionik 1 smatra da bavljenje šahom poboljšava koncentraciju, disciplinu, procese donošenja odluka te sposobnosti suočavanja sa stresom. Sudionik 2 vjeruje da je šah dobar za razvoj kvaliteta kao što su: upornost, odgovornost, samokritičnost, objektivnost, korektnost, poštivanje pravila, marljivost, borbenost, pažnja, samokontrola, kolegijalnost, racionalno korištenje vremena itd. Sudionik 3 od svega izdvaja koncentraciju i fokus kao glavne prednosti. Sudionik 4 izdvaja poboljšanje koncentracije kao prednost bavljenja šahom, ali navodi da šah uči sportskom ponašanju i samostalnom donošenju odluka te razvija algoritamsko razmišljanje. Sudionik 5 ističe da je šah dobar jer uči poštivanju protivnika, a razvija samokontrolu, potiče razmišljanje te učenici kroz njega kvalitetno provode slobodno vrijeme. Sudionik 6 navodi da šah uči poštovanju i sportskom ponašanju te razvija samostalno mišljenje i odgovorno donošenje odluka. Sudionik 7 kao prednosti šaha izdvaja što razvija disciplinu i organiziranost kod učenika te ih uči prihvaćanju poraza kao motivacije. Analizom odgovora iskristaliziralo se nekoliko područja: razvoja koncentracije kod učenika (S1, S2, S3 i S4), discipline i samokontrole (S1, S2, S3, S5 i S7) sportskog ponašanja i bliskih kategorija poput korektnosti, poštivanja pravila i poštivanja protivnika (S2, S4, S5, S6 i S7) te odgovornosti i samostalnosti u donošenju odluka (S1, S2, S4 i S6).

\section{ZAKLJUČAK}

Šah je u svojoj biti igra i kao takav je prirodan djeci, njihovoj znatiželji i želji za natjecanjem, stoga predlažemo značajniju implementaciju u život škola, bilo u vidu izvannastavnih ili izvanškolskih aktivnosti. U Gradu Zagrebu šah kao izvannastavnu aktivnost provode 32 osnovne škole, ali taj broj može i treba biti 
puno veći. Valja napomenuti i ograničenost ovog istraživanja samo na šah kao oblik izvannastavne aktivnosti. Projekt uvođenja šaha u škole je mnogo širi te u Zagrebu postoje i brojne škole koje organiziraju poučavanje šaha, ali u vidu izvanškolske aktivnosti. Iako bi bilo idealno da se šah kvalitetno provodi kao izvannastavna, a ne izvanškolska aktivnost, ponajprije zbog svoje pedagoške vrijednosti, ali i praktične jer su izvannastavne aktivnosti za učenike besplatne, bilo bi zanimljivo detaljnije ispitati i pojavnost i posebnosti provedbe šaha kao izvanškolske aktivnosti te komparirati dobivene podatke.

$\mathrm{Na}$ kraju, ovo istraživanje pokazalo je kako postoji interes za provedbu i razvoj šaha kao izvannastavne aktivnosti u školama i njenu daljnju popularizaciju. Istaknuta je i potreba uvođenja kvalitetnijeg stručnog ali i pedagoškog usavršavanja voditelja. Voditelji šaha kao izvannastavne aktivnosti svjesni su velikog značaja i prednosti koje šah razvija kod djece stoga na kraju ovoga rada još jednom ističemo potencijal koji nosi ova drevna igra, ali i potrebu sustavnijeg pedagoškog pristupa u implementaciji filozofije i prakse šaha putem šahovskih aktivnosti u živote učenika.

\section{LITERATURA}

1. Armstrong, T. (2008). Najbolje škole. Educa.

2. Binet, A. (1894). Psychologie des Grands Calculateurs et des Joueurs d'Echecs. Hachette.

3. Bognar, L,. Matijević, M. (1993). Didaktika. Školska knjiga

4. Cindrić, M. (1992). Izvannastavne i izvanškolske aktivnosti učenika osnovne škole. Život $i$ škola, 41, 49-67.

5. Cvetnić, V. (2014). Šah i kako ga lako naučiti igrati. Alfa.

6. de Groot, A. (1978). Thought and Choice in Chess. Mouton Publishers.

7. Dizdar, G. (2014). Prijedlog uvođenja šaha u nastavu osnovnih škola Republike Hrvatske. Hrvatski šahovski savez.

8. Ferguson, R. (1995). Chess in Education: Research Summary. A Review of Key Chess Research Studies. For the Borough of Manhattan Community College Chess in Education "A Wise Move" Conference. Dostupno na http://www.scholasticchess. mb.ca/docs/ciers.pdf

9. Ferguson, R. (1999). Teacher's Guide: Research and Benefits of Chess. U: P. McDonald (ur.), The Benefits of Chess in Education. Chess Federation of Canada.

10. FIDE (2009). FIDE - World chess federation. http://www.fide.com/fide.html [16.1.2018.]

11. FIDE (2012). AGON releases new chess player statistic from YOUGov. www. fide.com/component/content/article/1-fide-news/6376-agon-releases-new-chess-player-statistics-from-yougov.html [16.1.2018.]

12. FIDE (2014). Chess in schools - our global future. http://cis.fide.com/images/stories/ GlobalFuture2_2014/globalfuture_150dpi_small_6.5mb.pdf

13. FIDE Chess in schools comission. http://cis.fide.com/ [16.1.2018.]

14. FIDE trainers's comission. http://trainers.fide.com/ [16.1.2018.] 
15. Frank, A. (1978). Chess and Aptitudes. American Chess Foundation.

16. Foley, J. (2015). Ten reasons why chess is a sport http://londonchessconference.com/ a-question-of-sport/ [16.1.2018.]

17. Glasser, W. (2005). Kvalitetna škola: škola bez prisile. Educa.

18. Gobet, F., Campitelli, G. (2005). Educational benefits of chess instruction: A critical review. U: T. Redman (ur.), Chess and Education: Selected essays from the Koltanowski conference, (str. 124-143) Chess Program at the University of Texas at Dallas.

19. Golombek, H. (1980). Šahovska enciklopedija. Prosvjeta.

20. Jelovica, V. (2012). Utjecaj šaha na razvoj kognitivnih sposobnosti. Diplomski rad. Sveučilište u Zagrebu, Filozofski fakultet.

21. Kasparov, G. (2009). Kako život imitira šah. V.B.Z.

22. Liptrap, J. M. (1998). Chess and standard test scores. Chess Life, 3, 41-43.

23. Margulies, S. (1996). The Effect of Chess on Reading Scores: District Nine Chess Program Second Year Report. The American Chess Foundation. http://files.givewell. org/files/Analysis/margulies.pdf

24. Matijević, M. (2001). Alternativne škole: didaktičke i pedagoške koncepcije. Tipex.

25. Matijević, M., Radovanović, D. (2001). Nastava usmjerena na učenika. Školske novine.

26. Meyer, H. (2005). Što je dobra nastava? Erudita.

27. Mlinarević, V., Brust, M. (2009). Kvaliteta provedbe školskih izvannastavnih aktivnosti. Učiteljski fakultet.

28. Narodne novine (2008a). Državni pedagoški standard osnovnoškolskog sustava odgoja i obrazovanja. Zagreb: Narodne novine d.d., br. 63.

29. Narodne novine (2008b). Zakon o odgoju i obrazovanju u osnovnoj i srednjoj školi. Zagreb: Narodne novine, d.d., br. 87.

30. Nastavni plan i program za osnovnu školu. (2006). Ministarstvo znanosti, obrazovanja i športa.

31. Pavičić Vukičević, J. (2013). Šah - strateškom igrom do boljih kognitivnih rezultata djece rane dobi. U: B. Petrović-Sočo, A. Višnjić-Jevtić (ur.), Igra u ranom djetinjstvu. Proceedings of OMEP International Conference, Alfa.

32. Piaget, J. (1981). Psihologija inteligencije. Nolit.

33. Poljak, V. (1980). Didaktika. Školska knjiga.

34. Previšić, V. (1987). Izvannastavne aktivnosti i stvaralaštvo. Školske novine.

35. Previšić, V. (2000.), Slobodno vrijeme između pedagogijske teorije i odgojne prakse. Napredak 141(4), 403-410.

36. Sahlberg, P. (2012). Lekcije iz Finske: što svijet može naučiti iz obrazovne reforme u Finskoj. Školska knjiga.

37. Shenk, D. (2007). The Immortal Game. Souvenir Press.

38. Sušić, I. (2006). Škola šaha. Vlastita naklada.

39. Terhart, E. (2001). Metode poučavanja i učenja. Educa.

40. Trinchero, R. (2013). Can chess training improve Pisa scores in mathematics? An experiment in Italian primary schools. https://saintlouischessclub.org/sites/default/ files/TRINCHERO_ND_CHESS.pdf

41. Vrcelj, S. (2000). Školska pedagogija. Filozofski fakultet Rijeka. 